\title{
PENGARUH PENGUMUMAN LAPORAN KEUANGAN TERHADAP RETURN SAHAM PADA PERUSAHAAN GO PUBLIC DI BURSA EFEK INDONESIA
}

\author{
Idham lakoni \\ Program Studi manajemen Perusahaan \\ Fakultas Ekonomi Universitas Prof. Dr Hazairin, SH Bengkulu
}

ABSTRACT

Financial reports are important for investors as decision makers to invest their capital in certain issuers, announcements of financial statements can be good news or bad news for investors, so that at the time the financial statements of investors will react to stock prices which can ultimately affect stock returns that will received. This study aims to see differences in stock returns before and after the financial statements are announced, and to see whether the announcement of financial statements affect stock returns on companies that go public on the Indonesia Stock Exchange. This research was conducted by looking at changes in the average return of shares before and after the financial statements were announced. By using the purposive sampling method, a sample of 10 companies were selected on the Indonesia Stock Exchange. The observation period is carried out for 15 days, which is 7 days before the announcement of the financial statements, when the financial statements are announced and 7 days after the announcement of financial statements as of December 31, 2008 and 2009. In 2008 at the beginning of the observation (stock returns tend to be negative towards the announcement date financial reports there is a positive change because the information received by investors is good news as they expected, whereas in 2009 the initial observation of stock returns tended to be positive changes towards the negative approached the announcement of financial statements and returned to positive again after the announcement of financial statements this is because the information obtained by investors is not as good as expected. From the results of the study it can be seen that the announcement of financial statements is considered good news by investors so that it has a positive effect on stock returns, using tables and graphs. see changes in stock returns before and after the financial statements are announced, that is, after the financial statements are announced, stock returns tend to increase more than before the financial statements were announced.

Keywords: financial statements, stock returns.

\section{PENDAHULUAN}

Pasar modal merupakan tempat transaksi aset keuangan jangkah panjang atau long term financial asset, hal ini efektif untuk mempercepat pembangunan perekonomian suatu negara, dikarenakan pasar modal memiliki waktu jatuh tempoh lebih dari satu tahun. Sehingga masyarakat memiliki waktu yang cukup lama untuk menggerakan sektor-sektor produktif.

Pasar modal memiliki peran yang penting dalam perputaran perekonomian suatu negara, karena pasar modal memiliki fungsi yang saling melengkapi yaitu fungsi 


\section{CREATIVE RESEARCH MANAGEMENT JOURNAL-CRMJ Juni}

ekonomi dan fungsi keuangan. Dikatakan memiliki fungsi ekonomi karena pasar modal merupakan sarana tempat bertemunya dua pihak yang saling mengisi yaitu pihak yang memiliki kelebihan dana (investor) dan emiten yang membutuhkan dana baik jangka menengah maupun jangka panjang. Dimaksudkan dengan investor adalah perorangan atau lembaga yang menanamkan modalnya dalam bentuk efek dengan harapan mendapatkan imbalan (return) sedangakan emiten perusahaan yang menerbitkan efek untuk ditawarkan kepada masyarakat, agar dapat menggunaka dana yang dihimpun untuk kepentingan investasi tanpa harus menunggu tersedianya dana dari hasil operasi. Dengan adanya pasar modal ini, aktivasi perekonomian menjadi meningkat karena pasar modal merupakan alternatif pendanaan bagi perusahaan-perusahaan sehingga perusahaan dapat beroperasi dengan skala yang lebih besar dan akan berdampak pada meningkatnya pendapatan perusahaan dan kemakmuran masyarakat luas.

Pasar modal merupakan pasar abstrak sekaligus pasar konkrit dengan barang yang diperjual belikan bersifat abstrak, dan bentuk konkritnya adalah lembar surat-surat berharga di Bursa Efek. Berdasarkan UU no 8 tahun 1995 tentang pasar modal, Bursa Efek adalah pihak yang menyelenggarakan dan menyediakan sistem dan atau sarana untuk mempertemukan pihak penjual dan pembeli surat berharga dengan tujuan memperdagangkan surat berharga diantara mereka.

Salah satu surat berharga yang diperdagangkan di Bursa Efek Indonesia ini adalah saham, dimana saham merupakan bukti kepemilikan perusahaan yang artinya setiap saham menunjukkan satu suara kepemilikan. Saham merupakan surat berharga yang paling diminati oleh investor bila dibandingkan dengan surat berharga lainya yang ada dipasar modal hal ini disebabkan karena saham memiliki keuntungan return yang lebih besar dengan waktu yang relatif singkat (high return). Selain high return, saham juga memiliki kecendrungan high risk, suatu ketika harga saham juga dapat turun secara cepat. Dengan karakter high risk high return ini. Maka investor harus selalu memantau informasi mengenai harga saham yang sedang di pegangnya agar dapat mengambil keputusan yang tepat.

Informasi merupakan unsur penting bagi investor dan pelaku bisnis karena informasi menggambaran keadaan masa lalu maupun masa yang akan datang bagi kelangsungan perusahaan dan bagaimana pasaran efeknya. Informasi yang akurat mendasari pengambilan keputusan yang tepat sasaran untuk di analisis.

Salah satu sumber informasi yang mendasari pengambilan keputusan para investor adalah laporan keuangan, hal ini dikarenakan laporan keuangan menunjukan kondisi keuangan perusahaan secara keseluruhan dari laporan ini akan terbaca bagaimana kondisi keuangan perusahaan yang sesungguhnya baik kelebihannya maupun kekurangannya sehingga masyarakat dapat menganalisis bagaimana perkembangan perusahaan di masa yang akan datang, dimana informasi yang terkandung dapat berupa kabar yang baik maupun kabar yang buruk bagi para investor sehingga akan memacu reaksi mereka terhadap harga saham yang dapat berpengaruh terhadap return-return saham yang diterima. 


\section{CREATIVE RESEARCH MANAGEMENT JOURNAL-CRMJ Juni}

2018

\section{LANDASAN TEORI \\ Pengertian Pasar Modal}

Pasar modal merupakan suatu tempat bertemunya para penjual dan pembeli untuk melakukan transaksi dalam rangka memperoleh modal. Penjual dalam pasar modal merupakan merupakan perusahaan yang membutuhkan modal (emiten), sehimgga mereka berusaha untuk menjual efek-efek di pasar modal. Sedangkan pembeli modal di perusahaan yang menurut mereka menguntungkan. Dalam transaksi di pasar modal investor dapat langsung meneliti dan menganalisa keuntungan masing-masing perusahaan yang menawarkan modal menurut mereka menguntungkan dapat langsung membeli dan menjualnya kembali pada saat harga naik dalam pasar yang sama. Jadi dalam hal ini investor dapat juga menjadi penjual kepada para investor lainya (Kasmir 2010:207).

Menurut Santoso (2006:279) pasar modal (capital market) adalah pasar keuangan untuk dana-dana jangka panjang dan merupakan pasa yang konkret. Dana jangka panjang adalah dana yang jatuh temponya lebih dari satu tahun. Pasar modal dalam artian yang sempit adalah suatu tempat dalam pengertian fisik yang terorganisasi tempat efek-efek diperdagangkan yang disebut bursa efek.

Sedangkan menurut Rusdin (2008:1) merupakan kegiatan yang berhubungan dengan penawaran umum dan perdagangan efek, perusahaan public yang berkaitan dengan efek yang diterbitkan, serta lembaga dan profesi yang berkaitan dengan efek. Pasar modal menyediakan berbagai macam alternatif investasi bagi para investor selain itu juga pasar modal bertindak sebagai penghubung antara para investor dengan perusahaan atau pun instutusi pemerintah melalui perdagangan instrumen keuangan jangka panjang seperti saham.

\section{Peranan pasar modal}

Adapun peranan pasar modal menurut Rusdin (2008:2) sebagai berikut:

1. Pasar modal merupakan wahana mengalokasikan dana secara efesien. Investor dapat melakukan investasi pada beberapa perusahaan melalui pembelian efekefek yang baru ditawarkan ataupun yang diperdagangkan di pasar modal. Sebaliknya perusahaan dapat memperoleh dana yang di butuhkan dengan menawarkan instrumen keuangan jangka panjang melalui pasar modal tersebut.

2. Pasar modal sebagai alternatif investasi, pasar modal memudahkan alternatif berinvestasi dengan memberikan keuntungan dengan sejumlah resiko tertentu.

3. Memungkinkan para investor untuk memiliki perusahaan yang sehat dan berprospek baik. Perusahaan yang sehat dan mempunyai prospek yang baik, sebaiknya tidak hanya dimilik oleh sejumlah orang-orang tertentu saja, karena penyebaran kepemilikan secara luas akan mendorong perkembangan perusahaan menjadi lebih transparan.

4. Pelaksanaan manajemen perusahaan secara propesional dan transparan. Keikut sertaan masyarakat dalam kepemilikan perusahaan mendorng perusaahn untuk menerapakan manajemen secrara profesional, efisien dan berorientasi pada keuntungan, sehingga tercipta suatu kondisi keuntungan yang lebih baik bagi investor. 


\section{CREATIVE RESEARCH MANAGEMENT JOURNAL-CRMJ Juni}

5. Meningkatkan aktivitas ekonomi nasional dengan keberadaan pasar modal, perusahaan akan lebih memperoleh dana, sehingga akan mendorong perekonomian nasional menjadi lebih maju, yang selanjutnya akan menciptakan kesempatan yang luas, serta menigkatkan pendapatan bagi pemerintah.

Sedangkan menurut Darmadji dan Fakhrudin (2002: 2) menegnai peranan dan manfaat keberadaan pasar modal, yaitu: Pasar modal memiliki peran besar bagi perekonomian suatu Negara karena pasar modal menjalankan dua fungsi sekaligus, yaitu fungsi ekonomi dan fungsi keuangan. Pasar modal dikatakan memiliki fungsi ekonomi karena menyediakan fasilitas atau wahana yang mempertemukan antara pihak investor dan pihak issuer. Pasar modal juga dikatakan memiliki fungsi keuangan, karena pasar modal memberikan kemungkinan dan kesempatan memperoleh imbalan (return) bagi pemilik dana, sesuai dengan karakteristik investasi yang dipilih.

Berdasarkan definisi diatas, maka dapat diambil kesimpulan bahwa pasar modal memiliki peranan sebagai berikut:

1. Pasar modal menjalankan fungsi ekonomi. Dalam hal ini, pasar modal menyediakan fasilitas atau wahana yang mempertemukan dua kepentingan yaitu pihak yeng memiliki kelebihan dana (Investor) dan pihak yang memelukan dana (Issuer). Dengan adanya pasar modal maka pihak yang memiliki kelebihan dana dapat menginvestasikan dana tersebut dengan harapan memperoleh imbalan (return), sedangkan pihak issuer (dalam hal ini perusahaan) dapat memanfaatkan dana tersebut untuk kepentingan investasi tanpa harus menunggu dana dari operasi perusahaan.

2. Pasar modal memiliki fungsi keuangan. Dalam hal ini perusahaan menyediakan dana yang diperlukan oleh para investor dan issuer tanpa harus adanya keterlibatan secara langsung pihak-pihak tersebut dalam kepemilikan aktiva riil yang diperlukan untuk investasi tersebut.

\section{Pihak-Pihak Yang Terkait Dengan Pasar Modal}

Adanya pihak-pihak yang terkait dengan pasar modal menurut Tandelilin (2010:62) sebagai berikut :

1. Bapepam. Bapepam mempunyai kewenangan untuk mengatur dan memberikan izin serta mencabutnya bagi lembaga atau perorangan yang terlibat dipasar modal.

2. Perusahaan go public (Emiten). Perusahaan go public adalah pihak yang melakukan emisi atau yang telah melakukan penawaran umum untuk surat berharga. Pihak ini membutuhkan dana membelanjai operasi rencana investasi.

3. Pelaksanaan Bursa (BEI). Pasar Modal adalah pihak yang menyelenggarakan dan menyediakan system dan sarana untuk mempertemukan penawaran jual dan beli efek pihak lain dengan tujuan memperdagangkan efek diantara mereka.

4. Perusahaan Efek. Perusahaan Efek adalah perusahaan yang memiliki satu atau gabungan tiga kegiatan berikut ini antara lain sebagai berikut:

a) Penjamin emisi Efek adalah salah satu aktivitas pada perusahaan efek yang melakukan kontrak dengan emiten untuk melaksanakan penawaran 


\section{CREATIVE RESEARCH MANAGEMENT JOURNAL-CRMJ Juni}

umum dengan atau tanpa kewajiban untuk membeli sisa efek yang tidak terjual.

b) Perantara Perdagangan Efek atau Perusahaan Pialang adalah salah satu aktivitas pada perusahaan efek yang melakukan kegiatan usaha jual-beli efek untuk kepentingan sendiri atau pihak lain.

c) Manajer Investasi adalah pihak yang kegiatan usahanya mengelola portofolio efek untuk para nasabah atau mengelola portofolio investasi kolektif untuk sekelompok nasabah kecuali perusahaan asuransi, dana pensiun dan bank yang melakukan sendiri kegiatan usahanya berdasarkan perundang-undangan yang berlaku.

5. Lembaga Kliring dan Penyelesaian Penyimpanan. Lembaga Kliring dan penyelesaian penyimpanan adalah suatu lembaga yang menyelenggarakan kliring dan penyelesaian transaksi yang terjadi di bursa, serta penyimpanan efek dan penitipan harta untuk pihak lain.

6. Lembaga Penunjang Pasar Modal. Lima Lembaga penunjang pasar modal berikut ini merupakan lembaga yang menyediakan kegiatanyang membantu terselenggaranya pasar modal yang sehat.

7. Profesi Penunjang Pasar Modal. Profesi penunjang pasar modal terdiri dari :

a) Akuntan publik membantu emiten dalam menyusun prospektus dan laporan tahunan sehingga tersaji memenuhi ketentuan yang ditetapkan oleh Bapepam dan bursa efek.

b) Notaris berperan ketika emiten, perusahaan sekuritas dan pihak-pihak lainnya menyusun anggaran dasar dan kontrak-kontrak kegiatan.

c) Konsultan hukum membantu dalam melakukan kegiatannya agar sesuai dan tidak melanggar ketentuan yang berlaku dan aspek hukum lainnya.

d) Perusahaan penilai berperan dalam penentuan nilai wajar atas suatu aktiva perusahaan dalam proses emisi.

\section{Pengertian Laporan Keuangan}

Menurut Kasmir (2006:239) laporan keuangan nenunjukkan kondisi keuangan bank secara keseluruhan. Dari laporan ini akan terbaca kondisi keuangan bank secara keseluruhan. Dari laporan ini akan terbaca bagaimana kondisi bank yang sesungguhnya, termasuk kelemahan dan kekuatan yang dimiliki. Laporan ini juga menunjukkan kinerja manajemen bank satu periode. Keuntungan dengan membaca laporan ini pihak manajemen dapat memperbaiki kelemamahan yang ada serta mempertahankan kekuatan yang dimilikinya.

Sedangkan menurut Myer dikutip Munawir (2004:5) laporan keuangan adalah dua daftar yang disusun oleh akuntan pada akhir periode untuk satu perusahaan. Kedua daftar itu adalah daftar neraca atau daftar posisi keuangan dan daftar pendapatan atau daftar rugi-rugi. Pada waktu akhir-akhir ini sudah menjadi kebiasaan bagi perseroanperseroan untuk menambahkan daftar ketiga yaitu daftar surflus atau daftar laba yang tak dibagikan (laba yang ditahan). 


\section{CREATIVE RESEARCH MANAGEMENT JOURNAL-CRMJ Juni}

Sedangkan menurut Fahmi (2011:2) laporan keungan merupakan suatu informasi yang menggambarkan suatu kondisi keuangan perusahaan, dan lebih jauh informasi tersebut dapat dijadikan gambaran kinerja keuangan perusahaan tersebut.

Menurut Nitisusantro (2010:226) laporan keuangan merupakan laporan hasil usaha (income statement) menujukkan laba atau rugi dari hasil kegiatan operasional perusahaan dalam suatu periode, lazimnya selama satu tahun.

Secara lebih tegas Syofian Assa menjelaskan dalam Fahmi (2011:2) laporan keuangan merupakan pertanggungjawaban manajemen sumber daya yang dipercayakan kepadanya. Sedangkan menurut Fahmi (2012:23) laporan keuangan merupakan suatu informasi yang menggambarkan kondisi suatu perusahaan, dimana selanjutnya itu akan menggambarkan kinerja suatu perusahaan.

Selanjutnya menurut Munawir (2004:5) laporan keuangan adalah seni dari pada pencatatan, penggolongan dan peringkasan dari pada peristiwa-peristiwa dan kejadian yang setidak-tidaknya sebagian bersifat keuangan dengan cara yang setepat-tepatnya dan dengan menunjuk dan diyatakan dengan uang, serta penafsiran hal-hal yang timbul dari padanya.

Sedangkan menurut prinsip-prinsip akuntansi Indonesia dalam Munawir (2004:60) dikatakan bahwa laporan keuangan merupakan neraca dan perhitungan rugi laba serta segala keterangan-keterangan yang dimuat dalam lampiran-lampiran lain lapoaran sumber dan penggunakan dana-dana.

\section{Jenis-Jenis Laporan Keuangan}

Dalam praktiknya, secara umum ada lima macam jenis laporan keuangan yang bisa disusun (Kasmir, 2008:30) yaitu:

1. Neraca. Neraca (balance sheet) merupakan laporan yang menunjukkan posisi keuangan perusahaan pada tanggal tertentu. Arti dari posisi keuangan dimaksudkan adalah posisi jumlah dan jenis aktiva (harta) dan pasiva (kewajiban dan ekuitas) suatu perusahaan.

2. Laporan Laba Rugi. Laporan Laba Rugi (income statement) merupakan laporan keuangan yang menggambarkan hasil usaha perusahaan dalam suatu periode tertentu.

3. Laporan perubahan modal. Laporan perubahan modal merupakan laporan yang berisi jumlah dan jenis modal yang dimiliki pada saat ini. Laporan ini jarang dibuat bila tidak terjadi perubahan modal.

4. Laporan arus kas. Laporan arus kas merupakan laporan yang menunjukkan semua aspek yang berkaitan dengan kegiatan perusahaan, baik yang berpengaruh langsung atau tidak langsung terhadap kas.

5. Laporan catatan atas laporan keuanagan. Laporan catatan atas laporan keuangan merupakan laporan yang memberikan informasi apabila ada laporan keuangan yang memerlukan penjelasan tertentu.

\section{Pihak-pihak yang berkepentingan terhadap laporan keuangan}

Menurut Fahmi (2011:15) ada beberapa pihak yang selama ini dianggap memiliki kepentingan terhadap laporan keuangan suatu perusahaan, yaitu: 


\section{CREATIVE RESEARCH MANAGEMENT JOURNAL-CRMJ Juni}

1. Kreditur. Kreditur adalah pihak yang memberikan pinjaman baik dalam bentuk uang (money), barang (goods) maupun dalam bentuk jasa (service).

2. Investor. Investor disini bisa mereka yang membeli saham tersebut atau bahkan komisaris perusahaan. Seorang investor berkewajiban untuk mengetahui secara dalam kondisi perusahaan dimana ia akan berinvestasi atau pada saat ia sudah berinvestasi, karena dengan memahami laporan keuangan perusahaan tersebut berarti ia akan mengetahui berbagai informasi keuangan perusahaan. Investor menginginkan dana yang diinvestasikannya iti selalu berada dalam keadaan aman dan terus berkembang.

3. Akuntan publik. Akuntan publik adalah mereka yang ditugaskan untuk melakukan audit pada suatu perusahaan. Dan yang menjadi bahan audit suatu akuntan publik adalah laporan keuangan perusahaan, untuk melanjutkan pada hasil audit ia akan melaporkan dan penilaian dalam bentuk rekomendasi. Bagi sebuah perusahaan yang akan go public tanggung jawab seorang auditor menjadi tambah berat karena dengan penilaian seatu perusahaan bisa atau tidak dinyatakan laporan keuanganya memenuhi syarat untuk go public. Dalam konteks ini reputasi seorang auditor dipertaruhkan.

4. Karyawan perusahaan. Karyawan merupakan mereka yang terlibat secara penuhdisuatu perusahaan. Dan secara ekomoni meraka mempunyai ketergantungan yang besar yaitu pekerjaan dan penghasilan yang diterima dan perusahaan tempat bekerja telah begitu berperan dalam membantu kehidupannya, terutama jika karyawan tersebut telah berkeluarga. Dengan begitu posisi perusahaan yang tergambar dalam laporan keuangan menjadi bahan kajian bagi para karyawan dalam memosisikan keputusan kedepan nantinya.

5. Bapepam LK. Bapepam adalah badan pengawas pasar modal. Bagi suatu perusahaan yang akan go public maka perusahaan tersebut berkewajiban untuk memperlihatkan laporan keuangannya kepada bapepam dalam hal ini PT Bursa Efek Indonesia. Bapepam bertugas untuk mengamati dan mengawasi setiap kondisi perusahaan yang go public tersebut, termasuk berkewajiban untuk tidak menerima atau mengeluarkan perusahaan yang dianggap sudah tidak layak lagi untuk go public. Go public artinya perusahaan tersebut telah memutuskan untuk menjual sahamnya kepada publik dan siap untuk dinilai oleh publik secara terbuka. Saat pertama sekali perusahaan go public sering disebut dengan IPO ( initial publik offering). Perlu kita pahami tentang dua pasal yang berhubungan dengan pasar modal, yaitu:

a) Pasal 70 ayat 1 UU 1995 pasar modal menyebutkan yang dapat melakukan penawaran umum hanyalah emiten yang telah menyampaikan pernyataan pendaftaran kepada babpepam-LK untuk menawarkan atau menjual efek kepada masyarakat dan peryataan pendaftaran tersebut secara efektif.

b) Pasal 1 angka 19 UU 1995 pasar modal menyebutkan peryataan pendaftaran adalah dokumen yang wajib disampaikan kepada bapepam-LK oleh emiten dalam rangka penawaran umum atau perusahaan public. 


\section{CREATIVE RESEARCH MANAGEMENT JOURNAL-CRMJ Juni}

2018

\section{Kegunaan dan Tujuan laporan keuangan}

Berdasarkan konsep keuangan maka laporan keuangan sangat diperlukan untuk mengukur hasil usaha dan perkembangan perusahaan dari ke waktu dan untuk mengetahui sejauh mana perusahaan mencapai tujuannya. Bahwa laporan keuangan pada dasarnya merupakan hasil proses akuntansi yang dapat digunakan sebagai alat untuk berkomunikasi antara data keuangan atau aktivasi suatu perusahaan dalam pihakpihak yang berkepentingan dengan data atau aktivasi perusahaan tersebut. Sehingga laporan keuangan memegang perana yang luas dan mempunyai suatu posisi yang mempengaruhi dalam pengambilan keputusan (Fahmi, 2011:4).

Tujuan Laporan Keuangan

Tujuan laporan keuangan menurut Standar Akuntansi Keuangan (SAK) yang dikutip oleh Sawir (2005:2) adalah sebagai berikut:

a. Menyediakan informasi yang menyangkut posisi keuangan, kinerja serta perubahan posisi keuangan pada suatu perusahaan sehingga memberi manfaat bagi sejumlah besar pemakai (stakeholders) dalam pengambilan keputusan ekonomi.

b. Laporan keuangan disusun untuk memenuhi kebutuhan bersama oleh sebagian besar pemakainya, yang secara umum menggambarkan pengaruh keuangan dari kejadian masa lalu.

c. Laporan keuangan juga menunjukkan apa yang akan dilakukan manajemen atau pertanggungjawaban manajemen atas sumber daya yang dipercayakan kepadanya.

Tujuan laporan keuangan menurut Hanafi dan Halim (2003:30) adalah sebagai berikut:

1. Menberikan informasi yang bermanfaat untuk investor, kreditur dan pemakaian lainnya, saat ini maupun potensial (masa yang akan datang) untuk pembuatan keputusan investasi, kredit dan investasi semacam lainya.

2. Memberikan informasi yang bermanfaat untuk pemakaian eksternal, untuk memperkirakan jumlah, waktu dan ketidakpastian (yang berarti resiko) penerimaan kas yang berkaitan.

3. Untuk memperkirakan aliran kas perusahaan.

Menurut Kasmir (2006:240) secara umum tujuan pembuatan laporan keuangan adalah sebagai berikut:

1. Memberikan informasi keuangan tentang, jumlah aktiva dan jenis-jenis aktiva yang dimiliki.

2. Memberikan informasi keuangan tentang jumlah kewajiban dan jenis-jenis kewajiban baik jangkah pendek (lancer) maupun jangka panjang.

3. Memberikan informasi keuangan tentang jumlah modal dan jenis-jenis modal perusahaan pada waktu tertentu.

4. Memberikan informasi tentang hasil usaha yang tercermin dari jumlah pendapatan yang diperoleh dan sumber-sumber pendapatan perusahaan tersebut.

5. Memberikan informasi keuangan tentang biaya-biaya yang dikeluarkan berikut dengan jenis-jenis biaya yang dikeluarkan dalam periode.

6. Memberikan informasi tentang perubahan-perubahan yang terjadi dalam aktiva, kewajiban dan modal suatu perusahaan. 


\section{CREATIVE RESEARCH MANAGEMENT JOURNAL-CRMJ Juni}

7. Memberikan informasi tentang kinerja manajemen dalan suatu periode dari hasil laporan keuangan yang disajikan.

Menurut Fahmi (2011:5) untuk memberikan informasi kepada pihak yang membutuhkan tentang kondisi suatu perusahaan dari sudut angka-angka dalam satuan moneter. Dalam konteks laporan keuangan harus disadari oleh pihak mamajemen keuangan khususnya akuntan pembuat laporan keuangan bahwa ada 4 (empat) karakteristik utama laporan keuangan yang harus dipenuhi, 4 (empat) karakteristik tersebut adalah dapat dipahami, relevasi, dapat dipercaya dan dapat dibandingkan dngan penjelasan sebagai berikut:

1. Suatu informasi bermanfaat apabila dapat dipahami atau understandable oleh para penggunanya. Para pengguna laporan keungan adalah pihak-pihak yang berasal dari berbagai kalangan dengan latar belakang pendidikan, profesi dan budaya yang berbeda-beda. Laporan keuangan harus disajikan dngan bahasa yang sederhana, singkat, formal, dan mudah dipahami. Namun perlu diketahui, penyajian informasi yang mudah dipahamiada kalanya sulit dilakukan. Laporan keuangan sering diharuskan menggunakan istilah-istilah ilmu keuanganataupun industry yang sulit dipahamioleh orang-orang awam. Penyajian informasi tersebut tetap haruslilakukan karena sangat relevan bagi sebagian pengguna laporan keuangan.

2. Informasi yang ada pada laporan keuangan harus relevan dengan pengambilan keputusan. Sebab jika tidak, maka laporan keuangan tidak akan memberikan manfaat bagi para penggunanya dalam melakukan evaluasi keuangan entitas bisnis tersebut. Agar relevan, informasi yang ada pada laporan keuangan harus memiliki nilai prediktif sehingga dapat digunakan dalam melakukan predeksi keuangan. Suatu informasi dikatakan relevan apabila disajikan dengan memperhatikan prisip materialitas.

3. Informasi yang ada pada laporan keuangan akan sangat bermanfaat apabila disajikan dengan andal atau dapat dipercaya. Suatu laporan keuangan dapat dipercaya apabila disajikan secara jujur disamping itu, laporan keuangan harus disajikan dengan prinsip 'substance over form' atau atau penyajian yang lebih mengutamakan hakikat ekonomi ketimbang hakikat formal. Laporan keuangan harus disajikan dengan prinsip kehati-hatian atau koservatif dan lengkap.

4. Infomasi yang ada pada laporan keuangan harus memiliki sifat daya banding. Untuk mencapai kualitas tersebut, laporan keuangan harus disajikan secara komparatif dengan tahun-tahun sebelumnya. laporan keuangan harus disajikan secara komparatif sangat bermanfaat karena dapat digunakan untuk melakukan predeksi keuangan. Agar memiliki daya bandina, laporan keuangan juga harus menggunakan teknik-teknik dan basis-basis pengukuran dengan konsisten.

Menurut PAPI (Pedoman Akutansi Perbankan Indonesia) dalam Fahmi (2011:6) untuk memberikan informasi tentang posisi keuangan, kinerja perubahan ekuiditas, arus kas dan informasi lainya yang bermanfaat bagi pengguna laporan dalam rangka membuat keputusan ekonomi serta menunjukan pertanggung jawaban manajemen atas penggunaan sumber daya yang dipercayakan kepada mereka. 


\section{CREATIVE RESEARCH MANAGEMENT JOURNAL-CRMJ Juni}

\section{Pengertian Saham}

Menurut Kasmir (2010:209) saham merupakan surat berharga yang bersifat kepemilikan. Artinya si pemilik saham merupakan pemilik perusahaan. Semakin besar saham yang dimilikinya, maka semakin besar pula kekuasaanya di perusahaan tersebut. Keuntungan yang diperolih dikenal dengan nama deviden. Pembagian deviden ditentukan dalam rapat Umum Pemegang Saham (RUPS).

Menurut Triandaru, Santoso (2006:293) secara sederhana saham dapat didefinisikan sebagai tanda penyertaan atau pemilikan seseorang atau badan dalam suatu perusahaan. Wujud saham adalah selembar kertas yang menerangkan bahwa pemilik kertas tersebut adalah pemilik perusahaan yang menerbitkan kertas tersebut.

Menurut Rusdin (2008:68) saham adalah sertifikat yang menunjukkan bukti kepemilikan suatu perusahaan, dan pemegang saham memeliki hak klaim atas perusahaan dan aktiva perusahaan. Dalam praktiknya terdapat beberapa saham yang diperdagangkan dibedakan menurut cara peralihan danmanfaat yang diperoleh bagi pemegang saham. Nilai saham terbagi atas tiga jenis yaitu:

1. Nilai nominal (nilai pari) merupakan nilai yang tercantum dalam sertifikat saham yang bersangkutan, di Indonesia saham diterbitkan harus memiliki nilai nominal dan untuk satu jenis sahamyang sama pada suatu perusahan harus memliki satu jeni niliai nominal.

2. Nilai dasar pda prinsin harga dasar saham ditentukan oleh harga perdana saat saham tersebut diterbitkan, harga dasar ini akan berubah sejalan dengan dilakukannya berbagai tindakan emitin yang berhubungan dengan saham, antara lain: Right Issue, Stock Split, Waran, dll.

3. Nilai pasar merupakan harga suatau saham pada pasar yang sedang berlangsung, jika bursa sudah tutup maka harga pasar saham tersebut adalah harga penutupannya.

Sedangkan menurut Fahmi (2011:53) saham yang dimaksud disini adalah saham yang berasal dari perusahaan lain, yang dibeli oleh pihak manajemen perusahaan dan selanjutnya sewaktu-waktu bisa dijual kembali jika membutuhkan dana. Dan hasil keuntungan penjualan tersebut akan masuk ke kas perusahaan. Keputusan pembelian saham juga merupakan bentuk investasi perusahaan dalam bidang commercial paper artinya keputusan investment in commercial paper yang memiliki nilai profitable.

\section{Jenis Saham-Saham}

Berdasarkan atas cara peralihannya, saham dibedakan menjadi dua, yaitu: saham atas unjuk (bearer stock) dan saham atas nama (registeret stock) (Rusdin, 2008:69):

1. Saham atas unjuk (bearer stock) adalah saham yang tidak ada nama pemiliknya, agar mudah dipindah tangankan dari satu investor ke investor lain.

2. Saham atas nama (regesteret stock) adalah saham yang ditulis dengan jelas siapa pemiliknya. Dimana cara peralihannya harus melalui prosedur tertentu, yaitu dengan dokumen peralihan dan kemudian nama pemiliknya dicatat dalam buku perusahaan yang khusus membuat daftar nama pemegang saham. Apabila terjadi kehilangan, pemegang saham tersebut dengan mudah mendapat penggantinya. 
TABEL I

PERBEDAAN BEARER STOCK DENGAN REGESTERET STOCK

\begin{tabular}{|l|l|}
\hline \multicolumn{1}{|c|}{ Saham atas unjuk (bearer stock) } & \multicolumn{2}{|c|}{ Saham atas nama (regesteret stock) } \\
\hline Prosedur perdagangan mudah dan cepat & $\begin{array}{l}\text { Prosedur perdagannya perlu waktu, } \\
\text { karena perlu pemindahan nama } \\
\text { kepemilikan (regestrasi) }\end{array}$ \\
\hline Tidak perlu daftar pemilik saham & $\begin{array}{l}\text { Harus ada pihak yang mencatat nama } \\
\text { atau daftar pemilik saham }\end{array}$ \\
\hline Sulit diketahui dan mudah dipantau & $\begin{array}{l}\text { Nama pemilik saham mudah dikatahui } \\
\text { dan mudah dipantau }\end{array}$ \\
\hline Sulit diganti jika terjadi kehilangan & Kalau hilang mudah diganti \\
\hline Lebih mudah dipalsakan & Lebih sulit dipalsukan \\
\hline
\end{tabular}

Sumber: Rusdin (2006:69) Pasar modal

Faktor-faktor yang mempengaruhi harga saham

Ada beberapa kondisi-kondisi yang menentukan suatu saham itu akan mengalami fluktuasi, yaitu (Fahmi, 2011:57):

1) Kondisi mikro dam makro ekonomi.

2) Kebijakan perusahaan dalam memutuskan untuk ekspansi (perluasan usaha), seperti membuka kantor cabang (brand office), kantor cabang pembantu (sub brand office) baik yang dibuka di domistik maupun diluar negeri.

3) Pergantian direksi secara tiba-tiba.

4) Adanya direksi atau pihak komisaris perusahaan yang terlibat tindak pidana dan kasusnya sudah sampai dipengadilan.

5) Kinerja perusahaan yang terus mengalami penurunan dalam setiap waktunya.

6) Resiko sistematis (systematic risk), yaitu suatau bentuk risiko yang terkjadi secara menyeluruh dan telah ikut menyebabkan perusahaan ikut terlibat.

7) Efek dari psikologo pasar yang ternyata mampu menekan kondisi.

Menurut Weston dan Brigham dalam putri (2011:6), faktor-faktor yang mempengaruhi harga saham adalah: Laba per lembar saham, Tingkat bunga, Jumlah kas deviden yang diberikan, Jumlah laba yang didapat perusahaan, Tingkat risiko dan pengembalian.

\section{Manfaat Investasi Pada Saham.}

Keuntungan investasi saham menurut (Rusdin, 2011:56) sebagai berikut:

1) Deviden. Deviden adalah keuntungan perusahaan yang dibagikan kepada pemegang saham. Jumlah deviden yang akan dibagikan diusulkan oleh Dewan Dereksi dan disetujui didalam Rapat Umum Pemegang Saham.

2) Capital Gain. Capital gain adalah keuntungan yang diperoleh pemegang saham, ketika menjual sahamya atau dengan kata lain selisih harga jual dengan harga beli (Rusdin, 2011:57). 


\section{Resiko Investasi Saham}

Menurut Rusdin (2008:74) terdapat resiko investasi pada saham yaitu:

1) Tidak mendapatkan deviden. Jika emiten tidak dapat membukukan laba pada tahun berjalan atau Rapat Umum pemegang saham memutuskan untuk tidak membagikan dividen kepada pemegang saham karena laba yang diperoleh akan dipergunakan untuk ekspansi usaha.

2) Capital Loss. Investor akan mengalami capital loss, jika harga beli saham lebih besar dari harga jual.

3) Risiko likuidasi. Jika emiten bangkrut atau di likuidasi, para pemegang saham memiliki hak klaim terakhir terhadap aktifa perusahaan setelah seluruh kewajiban emiten dibayar.

4) Saham delisting dari bursa. Karena beberapa alasan tertentu, saham dapat dihapus pencatatannya (delisting) di Bursa sehingga pada akhirnya saham tersebut tidak dapat dipedagangkan.

\section{Pengertian Return Saham}

Menurut Jogiyanto (2010:205) Return saham merupakan hasil yang diperoleh dari investasi. Menurut Samsul (2006:291) Return saham adalah pendapatan yang dinyatakan dalam persentase dari modal awal investasi. Pendapatan investasi dalam saham ini meliputi keuntungan jual beli saham, dimana jika untung disebut capital gain dan jika rugi disebut capital loss

\section{Kerangka Pemikiran}

GAMBAR I

KERANGKA PEMIKIRAN

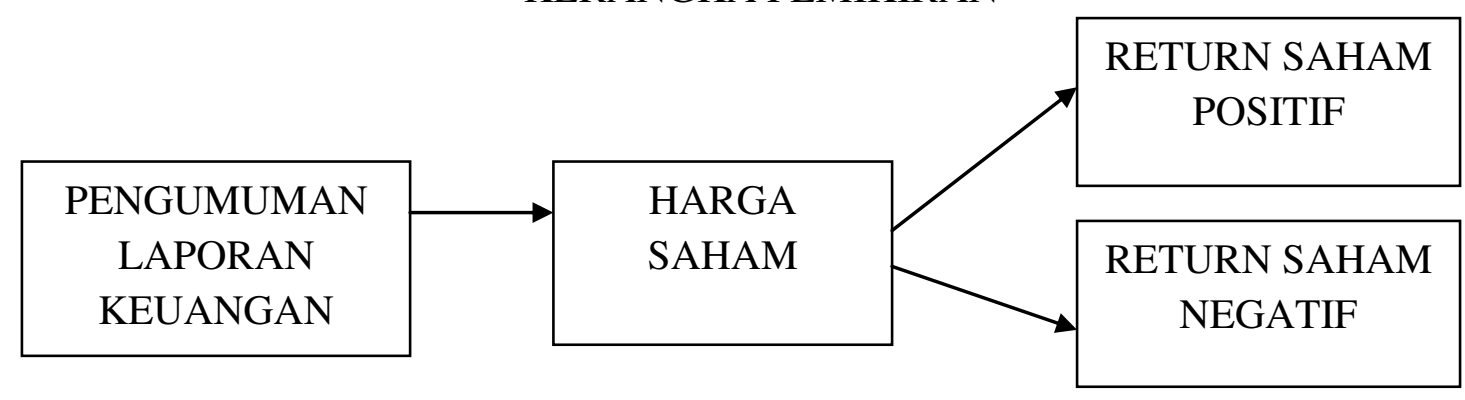

\section{HASIL PENELITIAN DAN PEMBAHASAN}

Dalam penelitian ini langkah pertama adalah mengidentifikasi tanggal pengumuman laporan keuangan. Kemudian menentukan tanggal periode pengamatan selama 15 hari perdagangan, yaitu 7 hari sebelum laporan keuangan diumumkan, pada saat laporan keuangan diumumkan, dan 7 hari setelah laporan keuangan diumumkan.

Langkah kedua adalah melakukan pemilihan sampel dengan Kriteria sebagai berikut: perusahaan sampel adalah perusahaan yang listed di Bursa Efek Indonesia selama periode pengamatan, yang mengumumkan laporan keuangannya ( laporan keuangan per 31 Desember tahun 2008 dan 2009, dan yang aktif melakukan perdagangan saham selama periode pengamatan. 
TABEL II

TANGGAL PENGUMUMAN LAPORAN KEUANGAN ( 2008-2009)

\begin{tabular}{|c|c|c|c|}
\hline \multirow{2}{*}{ NO } & \multirow{2}{*}{ KODE } & \multicolumn{2}{|c|}{ TANGGAL PENGUMUMAN LAPORAN } \\
& & TAHUN 2008 & TAHUN 2009 \\
\cline { 2 - 4 } & & 16 Maret 2009 & 09 Maret 2010 \\
\hline 1 & AALI & 06 April 2009 & 31 Maret 2010 \\
\hline 2 & ACES & 01 April 2009 & 01 April 2010 \\
\hline 3 & ADES & 02 Maret 2009 & 03 Maret 2010 \\
\hline 4 & ASII & 20 April 2009 & 22 April 2010 \\
\hline 5 & AKKU & 23 Maret 2009 & 01 April 2010 \\
\hline 6 & INTP & 20 April 2009 & 01 April 2010 \\
\hline 7 & GJTL & 03 April 2009 & 22 April 2010 \\
\hline 8 & KBLM & 23 Maret 2009 & 01 April 2010 \\
\hline 9 & SMGR & 16 Maret 2009 & 09 Maret 2010 \\
\hline 10 & SMCB &
\end{tabular}

Sumber: : ( Http://www.idx, 2008-2009)

TABEL III

HARGA SAHAM SEBELUM DAN SESUDAH PENGUMUMAN LAPORAN KEUANGAN TAHUN 2008

\begin{tabular}{|l|l|l|l|l|l|l|l|l|l|l|}
\hline \multirow{2}{*}{$\begin{array}{l}\text { Hari } \\
\text { ke }\end{array}$} & \multicolumn{10}{|c|}{ Nama Perusahaan } \\
\cline { 2 - 11 } & AALI & ACES & ADES & ASII & AKKU & INTP & GJTL & KBLM & SMGR & SMCB \\
\hline $\mathrm{t}_{-8}$ & 12,600 & 69 & 410 & 1,100 & 50 & 4,275 & 220 & 125 & 3,425 & 510 \\
\hline $\mathrm{t}_{-}$ & 11,850 & 69 & 420 & 1,135 & 50 & 4,325 & 210 & 125 & 3,450 & 510 \\
\hline $\mathrm{t}_{-}$ & 12,100 & 69 & 405 & 1,130 & 50 & 4,225 & 210 & 125 & 3,475 & 510 \\
\hline $\mathrm{t}_{-}$ & 12,500 & 68 & 400 & 1,130 & 50 & 4,275 & 210 & 125 & 3,425 & 510 \\
\hline $\mathrm{t}_{-}$ & 12,550 & 68 & 400 & 1,130 & 50 & 4,275 & 225 & 115 & 3,475 & 520 \\
\hline $\mathrm{t}_{-}$ & 12,600 & 73 & 400 & 1,130 & 50 & 4,325 & 240 & 125 & 3,500 & 520 \\
\hline $\mathrm{t}_{-}$ & 12,600 & 73 & 405 & 1,130 & 50 & 4,325 & 240 & 125 & 3,500 & 520 \\
\hline $\mathrm{t}_{-}$ & 12,600 & 73 & 405 & 1,130 & 50 & 4,325 & 240 & 125 & 3,500 & 520 \\
\hline $\mathrm{t}_{0}$ & 12,950 & 73 & 400 & 1,130 & 50 & 4,300 & 220 & 115 & 3,550 & 530 \\
\hline $\mathrm{t}_{1}$ & 12,500 & 73 & 430 & 1,080 & 50 & 4,550 & 215 & 115 & 3,650 & 520 \\
\hline $\mathrm{t}_{2}$ & 12,250 & 71 & 450 & 1,075 & 50 & 4,700 & 215 & 115 & 3,850 & 520 \\
\hline $\mathrm{t}_{3}$ & 12,600 & 71 & 450 & 1,110 & 50 & 4,925 & 210 & 115 & 3,850 & 540 \\
\hline $\mathrm{t}_{4}$ & 12,600 & 71 & 450 & 1,100 & 50 & 5,000 & 210 & 115 & 3,750 & 530 \\
\hline $\mathrm{t}_{5}$ & 12,600 & 71 & 430 & 1,100 & 50 & 5,000 & 210 & 115 & 3,750 & 530 \\
\hline $\mathrm{t}_{6}$ & 12,600 & 71 & 415 & 1,100 & 50 & 5,000 & 210 & 125 & 3,750 & 530 \\
\hline $\mathrm{t}_{7}$ & 12,700 & 74 & 415 & 1,125 & 50 & 5,050 & 210 & 125 & 3,850 & 540 \\
\hline
\end{tabular}

sumber: www.yahoofinance.co.id 2008 
TABEL IV

HARGA SAHAM SEBELUM DAN SESUDAH PENGUMUMAN LAPORAN KEUANGAN TAHUN 2009

\begin{tabular}{|l|l|l|l|l|l|l|l|l|l|l|}
\hline \multirow{2}{*}{$\begin{array}{l}\text { Hari } \\
\text { ke }\end{array}$} & \multicolumn{9}{|c|}{ Nama Perusahaan } \\
\cline { 2 - 12 } & AALI & ACES & ADES & ASII & AKKU & INTP & GJTL & KBLM & SMGR & SMCB \\
\hline $\mathrm{t}-8$ & 23,900 & 164 & 610 & 3,625 & 140 & 14,200 & 700 & 145 & 7,700 & 1,790 \\
\hline $\mathrm{t}-7$ & 23,850 & 166 & 610 & 3,625 & 140 & 14,400 & 700 & 145 & 7,650 & 1,820 \\
\hline $\mathrm{t}-6$ & 24,050 & 166 & 630 & 3,625 & 140 & 14,500 & 700 & 145 & 7,550 & 1,820 \\
\hline $\mathrm{t}-5$ & 23,900 & 166 & 630 & 3,625 & 140 & 14,500 & 700 & 145 & 7,550 & 1,820 \\
\hline $\mathrm{t}-4$ & 23,700 & 166 & 630 & 3,625 & 140 & 14,500 & 700 & 145 & 7,550 & 1,830 \\
\hline $\mathrm{t}-3$ & 23,700 & 166 & 630 & 3,625 & 140 & 14,400 & 720 & 145 & 7,550 & 1,830 \\
\hline $\mathrm{t}-2$ & 23,700 & 164 & 650 & 3,685 & 169 & 14,300 & 830 & 145 & 7,450 & 1,830 \\
\hline $\mathrm{t}_{-}-1$ & 24,400 & 164 & 650 & 3,620 & 169 & 14,250 & 800 & 145 & 7,300 & 1,830 \\
\hline $\mathrm{t}_{0}$ & 25,350 & 164 & 720 & 3,615 & 169 & 14,650 & 850 & 144 & 7,850 & 1,910 \\
\hline $\mathrm{t}_{1}$ & 24,950 & 165 & 720 & 3,605 & 120 & 14,650 & 850 & 135 & 7,850 & 2,000 \\
\hline $\mathrm{t}_{2}$ & 24,400 & 165 & 720 & 3,680 & 120 & 14,650 & 850 & 135 & 7,850 & 1,980 \\
\hline $\mathrm{t}_{3}$ & 24,650 & 165 & 720 & 3,680 & 120 & 14,650 & 850 & 135 & 7,850 & 1,970 \\
\hline $\mathrm{t}_{4}$ & 24,650 & 165 & 710 & 3,680 & 120 & 14,900 & 840 & 135 & 8,100 & 1,970 \\
\hline $\mathrm{t}_{5}$ & 24,650 & 165 & 690 & 3,900 & 120 & 14,950 & 830 & 135 & 8,150 & 1,970 \\
\hline $\mathrm{t}_{6}$ & 24,400 & 163 & 690 & 4,025 & 120 & 15,100 & 850 & 135 & 8,250 & 1,950 \\
\hline $\mathrm{t}_{7}$ & 24,400 & 165 & 690 & 3,995 & 120 & 14,750 & 830 & 130 & 8,200 & 1,950 \\
\hline
\end{tabular}

sumber: www.yahoofinance.co.id 2009

Menghitung return harian masing-masing saham perusahaan sampel selama periode pengamatan. Periode pengamatan ini ditetapkan pada 7 hari sebelum laporan keuangan diumumkan, pada saat laporan keuangan diumumkan, dan 7 hari setelah laporan keuangan diumumkan. 
TABEL $\mathrm{V}$

PERHITUNGAN RETURN SAHAM 2008

\begin{tabular}{|l|l|l|l|}
\hline \multirow{2}{*}{$\begin{array}{c}\text { Hari } \\
\mathrm{Ke}\end{array}$} & \multicolumn{3}{|c|}{ NAMA PERUSAHAAN } \\
\hline $\mathrm{t}-7$ & $\frac{11.850-12.600}{12.600}=0,05952$ & $\frac{69-69}{69}=0$ & $\frac{420-410}{410}=0,02439$ \\
\hline $\mathrm{t}-6$ & $\frac{12.100-11.850}{11.850}=0,02109$ & $\frac{69-69}{69}=0$ & $\frac{405-420}{420}=-0,03571$ \\
\hline $\mathrm{t}-5$ & $\frac{12.500-12.100}{12.100}=0,03306$ & $\frac{68-68}{68}=-0,01449$ & $\frac{400-405}{405}=-0,01234$ \\
\hline $\mathrm{t}-4$ & $\frac{12.550-12.500}{12.500}=0,00400$ & $\frac{68-68}{68}=0$ & $\frac{400-400}{400}=0$ \\
\hline $\mathrm{t}-3$ & $\frac{12.600-12.550}{12.550}=0,00398$ & $\frac{73-68}{68}=0$ & $\frac{400-400}{400}=0$ \\
\hline $\mathrm{t}-2$ & $\frac{12.600-12.600}{12.600}=0$ & $\frac{73-73}{73}=0$ & $\frac{405-400}{400}=0,01250$ \\
\hline $\mathrm{t}-1$ & $\frac{12.600-12.600}{12.600}=0$ & $\frac{73-73}{73}=0$ & $\frac{405-405}{405}=0$ \\
\hline $\mathrm{t}_{0}$ & $\frac{12950-12.600}{12.600}=0,02778$ & $\frac{73-73}{73}=0$ & $\frac{400-405}{405}=-0,01234$ \\
\hline $\mathrm{t}_{1}$ & $\frac{12.500-12.950}{12.950}=0,03475$ & $\frac{73-73}{73}=0$ & $\frac{430-400}{400}=0,07500$ \\
\hline $\mathrm{t}_{2}$ & $\frac{12.250-12.500}{12.500}=0,02000$ & $\frac{71-73}{73}=0$ & $\frac{450-430}{430}=0,04651$ \\
\hline $\mathrm{t}_{3}$ & $\frac{12.600-12.250}{12.250}=0,02857$ & $\frac{71-71}{71}=0$ & $\frac{450-450}{450}=0$ \\
\hline $\mathrm{t}_{4}$ & $\frac{12.600-12.600}{12.600}=0$ & $\frac{71-71}{71}=0$ & $\frac{450-450}{450}=0$ \\
\hline $\mathrm{t}_{5}$ & $\frac{12.600-12.600}{12.600}=0$ & $\frac{71-71}{71}=0$ & $\frac{430-450}{450}=-0,4444$ \\
\hline $\mathrm{t}_{6}$ & $\frac{12.600-12.600}{12.600}=0$ & $\frac{71-71}{71}=0$ & $\frac{415-430}{430}=0,03488$ \\
\hline $\mathrm{t}_{7}$ & $\frac{12.700-12.600}{12.600}=0$ & $\frac{74-71}{71}=0$ & $\frac{415-415}{415}=0$ \\
\hline
\end{tabular}




\begin{tabular}{|c|c|c|c|}
\hline \multirow{2}{*}{$\begin{array}{c}\text { Hari } \\
\text { Ke }\end{array}$} & \multicolumn{3}{|c|}{ NAMA PERUSAHAAN } \\
\hline & ASII & AKKU & INTP \\
\hline $\mathrm{t}-7$ & $\frac{1.135-1.110}{1.110}=0,02252$ & $\frac{50-50}{50}=0$ & $\frac{4.325-4.275}{4.275}=0,01169$ \\
\hline$t-6$ & $\frac{1.130-1.135}{1.135}=0$ & $\frac{50-50}{50}=0$ & $\frac{4.225-4325}{4.275}=-0,02339$ \\
\hline$t-5$ & $\frac{1.130-1.130}{1.130}=0$ & $\frac{50-50}{50}=0$ & $\frac{4.275-4.225}{4225}=0,01183$ \\
\hline $\mathrm{t}-4$ & $\frac{1.130-1.130}{1.130}=0$ & $\frac{50-50}{50}=0$ & $\frac{4.275-4.275}{4.275}=0$ \\
\hline$t-3$ & $\frac{1.130-1.130}{1.130}=0$ & $\frac{50-50}{50}=0$ & $\frac{4.325-4.275}{4.275}=0,01169$ \\
\hline $\mathrm{t}-2$ & $\frac{1.130-1.130}{1.130}=0$ & $\frac{50-50}{50}=0$ & $\frac{4.325-4.325}{4.325}=0$ \\
\hline$t-1$ & $\frac{1.130-1.130}{1.130}=0$ & $\frac{50-50}{50}=0$ & $\frac{4.325-4.325}{4.325}=0$ \\
\hline$t_{0}$ & $\frac{1.130-1.130}{1130}=0$ & $\frac{50-50}{50}=0$ & $\frac{4.300-4.325}{4.325}=-0,0057$ \\
\hline$t_{1}$ & $\frac{1.080-1.130}{1130}=-0,04425$ & $\frac{50-50}{50}=0$ & $\frac{4.550-4.300}{4.300}=0,05494$ \\
\hline$t_{2}$ & $\frac{1.075-1.080}{1080}=-0,00462$ & $\frac{50-50}{50}=0$ & $\frac{4.700-4.550}{4.550}=0,03297$ \\
\hline$t_{3}$ & $\frac{1110-1.075}{1.075}=0,03256$ & $\frac{50-50}{50}=0$ & $\frac{4.925-4.700}{4.700}=0,04787$ \\
\hline $\mathrm{t}_{4}$ & $\frac{1.110-1.110}{1.110}=0$ & $\frac{50-50}{50}=0$ & $\frac{5.000-4.925}{4.925}=0,01523$ \\
\hline$t_{5}$ & $\frac{1.100-1.100}{1.100}=0$ & $\frac{50-50}{50}=0$ & $\frac{5.000-5.000}{5000}=0$ \\
\hline $\mathrm{t}_{6}$ & $\frac{1.100-1.100}{1100}=0$ & $\frac{50-50}{50}=0$ & $\frac{5.000-5.000}{5.000}=0$ \\
\hline$t_{7}$ & $\frac{1.125-1.100}{1.100}=0,02273$ & $\frac{50-50}{50}=0$ & $\frac{5.050-5.000}{5.000}=0,01$ \\
\hline
\end{tabular}




\begin{tabular}{|c|c|c|c|}
\hline \multirow{2}{*}{$\begin{array}{c}\text { Hari } \\
\mathrm{Ke}\end{array}$} & \multicolumn{3}{|c|}{ NAMA PERUSAHAAN } \\
\hline & GJTL & KBLM & SMGR \\
\hline$t-7$ & $\frac{210-220}{220}=-0,04545$ & $\frac{125-125}{125}=0$ & $\frac{3.450-3.425}{3.425}=0,00729$ \\
\hline $\mathrm{t}-6$ & $\frac{210-210}{210}=0$ & $\frac{125-125}{125}=0$ & $\frac{3.475-3450}{3.450}=0,00725$ \\
\hline $\mathrm{t}-5$ & $\frac{210-210}{210}=0$ & $\frac{125-125}{125}=0$ & $\frac{3.425-3.475}{3.475}=-0,0143$ \\
\hline$t-4$ & $\frac{225-210}{210}=0,07143$ & $\frac{115-125}{125}=-0,08$ & $\frac{3.4753 .425}{3.425}=0,01459$ \\
\hline$t-3$ & $\frac{240-225}{225}=0,06667$ & $\frac{125-115}{115}=0,08696$ & $\frac{3.500-3.475}{3.475}=0,00719$ \\
\hline$t-2$ & $\frac{240-240}{240}=0$ & $\frac{125-125}{125}=0$ & $\frac{3.500-3.500}{3.500}=0$ \\
\hline$t-1$ & $\frac{240-240}{240}=0$ & $\frac{125-125}{125}=0$ & $\frac{3.500-3.500}{3.500}=0$ \\
\hline$t_{0}$ & $\frac{220-240}{240}=-0,08333$ & $\frac{115-125}{125}=0$ & $\frac{3.550-3.500}{3.500}=0,01428$ \\
\hline $\mathrm{t}_{1}$ & $\frac{215-220}{220}=-0,02273$ & $\frac{115-115}{115}=0$ & $\frac{3.650-3.550}{3.550}=0,02817$ \\
\hline$t_{2}$ & $\frac{215-215}{215}=0$ & $\frac{115-115}{115}=0$ & $\frac{3.850-3.650}{3.650}=0,05479$ \\
\hline $\mathrm{t}_{3}$ & $\frac{210-215}{215}=-0,02325$ & $\frac{115-115}{115}=0$ & $\frac{3.850-3.850}{3.850}=0$ \\
\hline $\mathrm{t}_{4}$ & $\frac{210-210}{210}=0$ & $\frac{115-115}{115}=0$ & $\frac{3.750-3.850}{3.850}=-0,0259$ \\
\hline$t_{5}$ & $\frac{210-210}{210}=0$ & $\frac{115-115}{115}=0$ & $\frac{3.750-3.750}{3.750}=0$ \\
\hline $\mathrm{t}_{6}$ & $\frac{210-210}{210}=0$ & $\frac{125-115}{115}=0,08696$ & $\frac{3.750-3.750}{3.750}=3.750$ \\
\hline$t_{7}$ & $\frac{210-210}{210}=0$ & $\frac{125-125}{125}=0$ & $\frac{3.850-3.750}{3.750}=0,02667$ \\
\hline
\end{tabular}




\begin{tabular}{|l|l|}
\hline $\begin{array}{l}\text { Hari } \\
\text { Ke }\end{array}$ & \multicolumn{1}{|l}{ NAMA PERUSAHAAN } \\
\hline$t_{-}$ & $\frac{510-510}{510}=0$ \\
\hline$t_{-}$ & $\frac{510-510}{510}=0$ \\
\hline$t_{-}$ & $\frac{510-510}{510}=0$ \\
\hline$t_{-}$ & $\frac{520-510}{510}=0,01961$ \\
\hline$t_{-} 3$ & $\frac{520-520}{520}=0$ \\
\hline$t_{-}$ & $\frac{520-520}{520}=0$ \\
\hline$t_{-}-$ & $\frac{520-520}{520}=0$ \\
\hline$t_{0}$ & $\frac{530-520}{520}=0,01923$ \\
\hline$t_{1}$ & $\frac{520-530}{530}=-0,01887$ \\
\hline$t_{2}$ & $\frac{520-520}{520}=0$ \\
\hline$t_{3}$ & $\frac{540-520}{520}=0,03846$ \\
\hline$t_{4}$ & $\frac{530-540}{540}=0$ \\
\hline$t_{5}$ & $\frac{530-530}{530}=0$ \\
\hline
\end{tabular}


TABEL VI

PERHITUNGAN RETURN SAHAM 2009

\begin{tabular}{|c|c|c|c|}
\hline \multirow{2}{*}{$\begin{array}{l}\text { Har } \\
\mathrm{Ke}\end{array}$} & \multicolumn{3}{|c|}{ NAMA PERUSAHAAN } \\
\hline & ALLI & ACES & ADES \\
\hline \multirow[t]{2}{*}{$t_{-7}$} & $23.850-23.900=$ & $166-146=013699$ & $610-610-0$ \\
\hline & $23.900=$ & $146=0,13699$ & $610=0$ \\
\hline \multirow[t]{2}{*}{$\mathrm{t}-6$} & $24.050-23.850=0.00838$ & $166-166=0$ & $630-610=0.03279$ \\
\hline & $23.850=0,00838$ & $\frac{166}{16}=0$ & $610=0,032 / 9$ \\
\hline \multirow[t]{2}{*}{$t_{-5}$} & $23.900-24.050$ & $166-166$ & $630-630-0$ \\
\hline & $24.050=$ & $166=$ & $630=0$ \\
\hline \multirow[t]{2}{*}{$t-4$} & $23.700-23.900$ & $166-166$ & $630-630$ \\
\hline & 23.900 & $166=$ & $630=$ \\
\hline \multirow[t]{2}{*}{$t-3$} & $\underline{23.700-23.700}=0$ & $166-166=$ & $630-630=$ \\
\hline & $23.700=0$ & $\frac{166}{166}=0$ & $\frac{630}{60}=0$ \\
\hline \multirow[t]{2}{*}{$\mathrm{t}-2$} & $23.700-23.700=0$ & $164-166=-0017$ & $650-630$ \\
\hline & $\frac{23.700}{2}=0$ & $\frac{166}{166}=-0,01205$ & $630=0,03175$ \\
\hline \multirow[t]{2}{*}{$t-1$} & $24.400-23.700=002953$ & $164-164$ & $650-650$ \\
\hline & $23.700=0,02953$ & $\frac{164}{164}=0$ & $\frac{650}{60}=0$ \\
\hline \multirow[t]{2}{*}{$t_{0}$} & $25.350-24.400$ & $164-164$ & $720-650$ \\
\hline & $24.400=0,03893$ & $\frac{164}{164}=0$ & $\frac{650}{650}=0,10769$ \\
\hline \multirow[t]{2}{*}{$t_{1}$} & $24.950-25.350$ & $165-164$ & $720-720$ \\
\hline & $25.350=-0,01578$ & $164=0,00609$ & $7720=0$ \\
\hline \multirow[t]{2}{*}{$\mathrm{t}_{2}$} & $24.400-24.950=$ & $165-165=0$ & $720-720=0$ \\
\hline & $24.950=$ & $\frac{165}{165}=0$ & $720=0$ \\
\hline \multirow[t]{2}{*}{$t_{3}$} & $24.650-24.400=0.01024$ & $165-165-0$ & $720-720$ \\
\hline & $24.400=0,01024$ & $165=0$ & $720=0$ \\
\hline \multirow[t]{2}{*}{$t_{4}$} & $24.650-24.650$ & $165-165$ & $710-720$ \\
\hline & $24.650=0$ & $\frac{165}{165}=0$ & $720=-0,0138$ \\
\hline \multirow[t]{2}{*}{$t_{5}$} & $24.650-24.650$ & $165-165$ & $690-710$ \\
\hline & $24.650=0$ & $\frac{165}{165}=0$ & $710=-0,02817$ \\
\hline \multirow[t]{2}{*}{$t_{6}$} & $24.400-24.650$ & $165-165$ & $690-690$ \\
\hline & 24.650 & $\frac{165}{165}=0$ & $690=$ \\
\hline \multirow[t]{2}{*}{$t_{7}$} & $24.400-24.400$ & $165-165=$ & $690-690=$ \\
\hline & 24.400 & 165 & 690 \\
\hline
\end{tabular}




\begin{tabular}{|c|c|c|c|}
\hline Hari & \multicolumn{3}{|c|}{ NAMA PERUSAHAAN } \\
\hline $\mathrm{Ke}$ & ASII & AKKU & INTP \\
\hline$t-7$ & $\frac{3.625-3.625}{3.625}=0$ & $\frac{140-140}{140}=0$ & $\frac{14.400-14.200}{14.200}=0,01408$ \\
\hline $\mathrm{t}-6$ & $\frac{3.625-3.625}{3.625}=0$ & $\frac{140-140}{140}=0$ & $\frac{14.500-14.400}{14.400}=0,00694$ \\
\hline$t-5$ & $\frac{3.625-3.625}{3.625}=0$ & $\frac{140-140}{140}=0$ & $\frac{14.500-14.500}{14.500}=0$ \\
\hline $\mathrm{t}-4$ & $\frac{3.625-3.625}{3.625}=0$ & $\frac{140-140}{140}=0$ & $\frac{14.500-14.500}{14.500}=0$ \\
\hline$t-3$ & $\frac{3.625-3.625}{3.625}=0$ & $\frac{140-140}{140}=0$ & $\frac{14.400-14.500}{14.500}=-0,0068$ \\
\hline$t-2$ & $\frac{3.685-3.625}{3.625}=0,01655$ & $\frac{168-140}{140}=0,20714$ & $\frac{14.300-14.400}{14.400}=-$ \\
\hline $\mathrm{t}-1$ & $\frac{3.620-3.685}{3.685}=-0,01764$ & $\frac{168-140}{140}=0,20714$ & $\frac{14.250-14.300}{14.300}=-0,0034$ \\
\hline $\mathrm{t}_{0}$ & $\frac{3.615-3.620}{3.625}=-0,00139$ & $\frac{168-140}{140}=0,20714$ & $\frac{14.650-14.250}{14.250}=0,02807$ \\
\hline $\mathrm{t}_{1}$ & $\frac{3.605-3.615}{3.615}=-0,0027$ & $\frac{120-169}{169}=-0,2899$ & $4 \frac{14.650-14.650}{14.650}=0$ \\
\hline$t_{2}$ & $\frac{3.680-3.605}{3.605}=0,02080$ & $\frac{120-120}{120}=0$ & $\frac{14.650-14.650}{14.650}=0$ \\
\hline$t_{3}$ & $\frac{3.680-3.680}{3.680}=0$ & $\frac{120-120}{120}=0$ & $\frac{14.650-14.650}{14.650}=0$ \\
\hline $\mathrm{t}_{4}$ & $\frac{3.680-3.680}{3.680}=0$ & $\frac{120-120}{120}=0$ & $\frac{14.900-14.650}{14.650}=0,01706$ \\
\hline$t_{5}$ & $\frac{3.900-3.680}{3.680}=0,05978$ & $\frac{120-120}{120}=0$ & $\frac{14.950-14.900}{14.900}=0,00335$ \\
\hline $\mathrm{t}_{6}$ & $\frac{4.025-3.900}{3.900}=0,03205$ & $\frac{120-120}{120}=0$ & $\frac{15.100-14.950}{14.950}=0,01003$ \\
\hline$t_{7}$ & $\frac{3.995-4.025}{4.025}=-0,00745$ & $\frac{120-120}{120}=0$ & $\frac{14.750-15.100}{15.100}=-0,0231$ \\
\hline
\end{tabular}




\begin{tabular}{|c|c|c|c|}
\hline \multirow{2}{*}{$\begin{array}{l}\text { Hari } \\
\mathrm{Ke}\end{array}$} & \multicolumn{3}{|c|}{ NAMA PERUSAHAAN } \\
\hline & GJTL & KBLM & SMGR \\
\hline $\mathrm{t}-7$ & $\frac{700-700}{700}=0$ & $\frac{145-145}{145}=0$ & $\frac{7.650-7.700}{7.700}=-0,00649$ \\
\hline $\mathrm{t}-6$ & $\frac{700-700}{700}=0$ & $\frac{145-145}{145}=0$ & $\frac{7.550-7.650}{7.650}=-0,0130$ \\
\hline $\mathrm{t}-5$ & $\frac{700-700}{700}=0$ & $\frac{145-145}{145}=0$ & $\frac{7.550-7.550}{7.550}=0$ \\
\hline $\mathrm{t}-4$ & $\frac{700-700}{700}=0$ & $\frac{145-145}{145}=0$ & $\frac{7.550-7.550}{7.550}=0$ \\
\hline $\mathrm{t}-3$ & $\frac{720-700}{700}=0,02857$ & $\frac{145-145}{145}=0$ & $\frac{7.550-7.550}{7.550}=0$ \\
\hline $\mathrm{t}-2$ & $\frac{830-720}{720}=0,15278$ & $\frac{145-145}{145}=0$ & $\frac{7.450-7.550}{7.550}=-0,01324$ \\
\hline $\mathrm{t}-1$ & $\frac{800-830}{830}=-0,03614$ & $\frac{145-145}{145}=0$ & $\frac{7.300-7.450}{7.450}=-0,02013$ \\
\hline $\mathrm{t}_{0}$ & $\frac{850-800}{800}=0,0625$ & $\frac{144-145}{145}=-0,00689$ & $\frac{7.850-7.300}{7.300}=0,07534$ \\
\hline $\mathrm{t}_{1}$ & $\frac{850-800}{800}=0,0625$ & $\frac{135-144}{144}=-0,06250$ & $\frac{7.850-7.850}{7.850}=0$ \\
\hline $\mathrm{t}_{2}$ & $\frac{850-800}{800}=0,0625$ & $\frac{135-135}{135}=0$ & $\frac{7.850-7.850}{7.850}=0$ \\
\hline $\mathrm{t}_{3}$ & $\frac{850-800}{800}=0,0625$ & $\frac{135-135}{135}=0$ & $\frac{7.850-7.850}{7.850}=0$ \\
\hline $\mathrm{t}_{4}$ & $\frac{840-850}{850}=-0,01176$ & $\frac{135-135}{135}=0$ & $\frac{8.100-7.850}{7.850}=0,03185$ \\
\hline $\mathrm{t}_{5}$ & $\frac{830-840}{840}=-0,01190$ & $\frac{135-135}{135}=0$ & $\frac{8.150-8.100}{8.100}=0,00617$ \\
\hline $\mathrm{t}_{6}$ & $\frac{850-830}{830}=0,02409$ & $\frac{135-135}{135}=0$ & $\frac{8.250-8.150}{8.150}=0,01227$ \\
\hline $\mathrm{t}_{7}$ & $\frac{830-850}{850}=-0,02352$ & $\frac{130-135}{135}=-0,03704$ & $\frac{8.200-8.250}{8.250}=-0,00606$ \\
\hline
\end{tabular}




\begin{tabular}{|c|c|}
\hline Hari & NAMA PERUSAHAAN \\
\hline $\mathrm{Ke}$ & SMCB \\
\hline$t-7$ & $\frac{1.820-1.790}{17.90}=0,01675$ \\
\hline $\mathrm{t}-6$ & $\frac{1.820-1.820}{1.820}=0$ \\
\hline$t-5$ & $\frac{1.820-1.820}{1.820}=0$ \\
\hline $\mathrm{t}-4$ & $\frac{1.830-1.820}{1.820}=0$ \\
\hline$t-3$ & $\frac{1.830-1.820}{1.820}=0$ \\
\hline $\mathrm{t}-2$ & $\frac{1.830-1.820}{1.820}=0$ \\
\hline$t-1$ & $\frac{1.830-1.820}{1.820}=0$ \\
\hline $\mathrm{t}_{0}$ & $\frac{1.910-1.830}{1.830}=0,04371$ \\
\hline $\mathrm{t}_{1}$ & $\frac{2.000-1.910}{1.910}=0,04712$ \\
\hline $\mathrm{t}_{2}$ & $\frac{1.980-2.000}{2.000}=-0,01$ \\
\hline$t_{3}$ & $\frac{1.970-1.980}{1.980}=-0,00505$ \\
\hline $\mathrm{t}_{4}$ & $\frac{1.970-1.970}{1.970}=0$ \\
\hline$t_{5}$ & $\frac{1.970-1.970}{1.970}=0$ \\
\hline $\mathrm{t}_{6}$ & $\frac{1.950-1.970}{1.970}=-0,01015$ \\
\hline$t_{7}$ & $\frac{1.950-1.950}{1.950}=0$ \\
\hline
\end{tabular}

Sumber: Data diolah 2013 
Langkah keempat adalah menghitung return rata-rata saham dan komulasinya seluruh perusahaan sampel, return positif diperoleh apabila harga saham pada hari $t$ lebih besar daripada harga saham hari sebelum t. sedangkan return negatif diperoleh apabila harga saham hari t lebih kecil daripada harga saham sebelum hari t.

TABEL VII

PERHITUNGAN AVERAGE RETURN SAHAM 2008 DAN 2009

\begin{tabular}{|l|l|l|}
\hline \multirow{2}{*}{$\begin{array}{l}\text { Hari } \\
\mathrm{Ke}\end{array}$} & \multicolumn{2}{|c|}{ Tahun } \\
\cline { 2 - 3 } $\mathrm{t}-\mathrm{-}$ & $\frac{-0,0391}{10}=-0,00391$ & $\frac{0,15924}{10}=0,01592$ \\
\hline $\mathrm{t}_{-}$ & $\frac{-0,03076}{10}=-0,00308$ & $\frac{0,03504}{10}=0,00350$ \\
\hline $\mathrm{t}_{-5}$ & $\frac{0,00367}{10}=0,00037$ & $\frac{-0,00623}{10}=-0,00062$ \\
\hline $\mathrm{t}_{-}$ & $\frac{-0,02963}{10}=-0,00296$ & $\frac{-0,00288}{10}=-0,00029$ \\
\hline $\mathrm{t}_{-3}$ & $\frac{0,18860}{10}=0,01886$ & $\frac{0,03546}{10}=0,00355$ \\
\hline $\mathrm{t}_{-2}$ & $\frac{0,07917}{10}=0,00792$ & $\frac{0,37599}{10}=0,03760$ \\
\hline $\mathrm{t}_{-}-$ & $\frac{0,00000}{10}=0,00000$ & $\frac{-0,04787}{10}=-0,00479$ \\
\hline $\mathrm{t}_{0}$ & $\frac{0,01871}{10}=0,00187$ & $\frac{0,34797}{10}=0,03480$ \\
\hline $\mathrm{t}_{1}$ & $\frac{0,05756}{10}=0,00576$ & $\frac{-0,31778}{10}=-0,03178$ \\
\hline $\mathrm{t}_{2}$ & $\frac{0,12225}{10}=0,01222$ & $\frac{-0,01124}{10}=-0,00112$ \\
\hline $\mathrm{t}_{3}$ & $\frac{0,12421}{10}=0,01242$ & $\frac{0,00519}{10}=0,00052$ \\
\hline $\mathrm{t}_{4}$ & $\frac{-0,02908}{10}=-0,00291$ & $\frac{0,02326}{10}=0,00233$ \\
\hline $\mathrm{t}_{5}$ & $\frac{-0,04444}{10}=-0,00444$ & $\frac{0,02923}{10}=0,00292$ \\
\hline $\mathrm{t}_{6}$ & $\frac{0,12184}{10}=0,01218$ & $\frac{0,03647}{10}=0,00365$ \\
\hline $\mathrm{t}_{7}$ & $\frac{0,12845}{10}=0,01284$ & $\frac{-0,09725}{10}=-0,00972$ \\
\hline
\end{tabular}

Sumber :Data diolah 2013 


\section{CREATIVE RESEARCH MANAGEMENT JOURNAL-CRMJ Juni \\ 2018}

Langkah selanjutnya adalah menganalisis return rata-rata tersebut untuk mengetahui apakah laporan keuangan berpengaruh terhadap return saham pada perusahaan go public di Bursa Efek Indonesia, untuk mengetahui adanya perubahan return saham yang disebabkan oleh pengumuman laporan keuangan pada perusahaan yang go publik di bursa efek Indonesia, dilakukan dengan menghitung selisih antara harga saham hari t dengan harga saham hari sebelum t. return yang diperoleh investor yaitu positif atau negatif.

TABEL VIII

RETURN SAHAM TAHUN 2008 DAN 2009

\begin{tabular}{|c|c|c|}
\hline Hari ke & Return 2008 & Return 2009 \\
\hline-7 & -0.03908 & 0.15924 \\
\hline-6 & -0.03076 & 0.03504 \\
\hline-5 & 0.00367 & -0.00623 \\
\hline-4 & -0.02963 & -0.00288 \\
\hline-3 & 0.18860 & 0.03546 \\
\hline-2 & 0.07917 & 0.37599 \\
\hline-1 & 0.00000 & -0.04787 \\
\hline 0 & 0.01871 & 0.34797 \\
\hline 1 & 0.05756 & -0.31778 \\
\hline 2 & 0.12225 & -0.01124 \\
\hline 3 & 0.12421 & 0.00519 \\
\hline 4 & -0.02908 & 0.02326 \\
\hline 5 & -0.04444 & 0.02923 \\
\hline 6 & 0.12184 & 0.03647 \\
\hline 7 & 0.12845 & -0.09725 \\
\hline
\end{tabular}

Sumber: data diolah 2013

Untuk lebih jelas melihat perbedaan return saham sebelum dan setelah laporan keuangan diumumkan, maka peneliti melihat perubahan return rata-rata saham dengan menggunakan tabel dan grafik. 
TABEL IX

AVERAGE RETURN SAHAM ( 2008-2009)

\begin{tabular}{|c|c|c|}
\hline Hari ke & Average return $(\bar{R}) 2008$ & Average return $(\bar{R}) 2009$ \\
\hline-7 & -0.00391 & 0.01592 \\
\hline-6 & -0.00308 & 0.00350 \\
\hline-5 & 0.00037 & -0.00062 \\
\hline-4 & -0.00296 & -0.00029 \\
\hline-3 & 0.01886 & 0.00355 \\
\hline-2 & 0.00792 & 0.03760 \\
\hline-1 & 0.00000 & -0.00479 \\
\hline 0 & 0.00187 & 0.03480 \\
\hline 1 & 0.00576 & -0.03178 \\
\hline 2 & 0.01222 & -0.00112 \\
\hline 3 & 0.01242 & 0.00052 \\
\hline 4 & -0.00291 & 0.00233 \\
\hline 5 & -0.00444 & 0.00292 \\
\hline 6 & 0.01218 & 0.00365 \\
\hline 7 & 0.01284 & -0.00972 \\
\hline
\end{tabular}

Sumber: Data diolah 2013 


\section{GAMBAR II \\ GRAFIK AVERAGE RETURN SAHAM ( 2008-2009)}

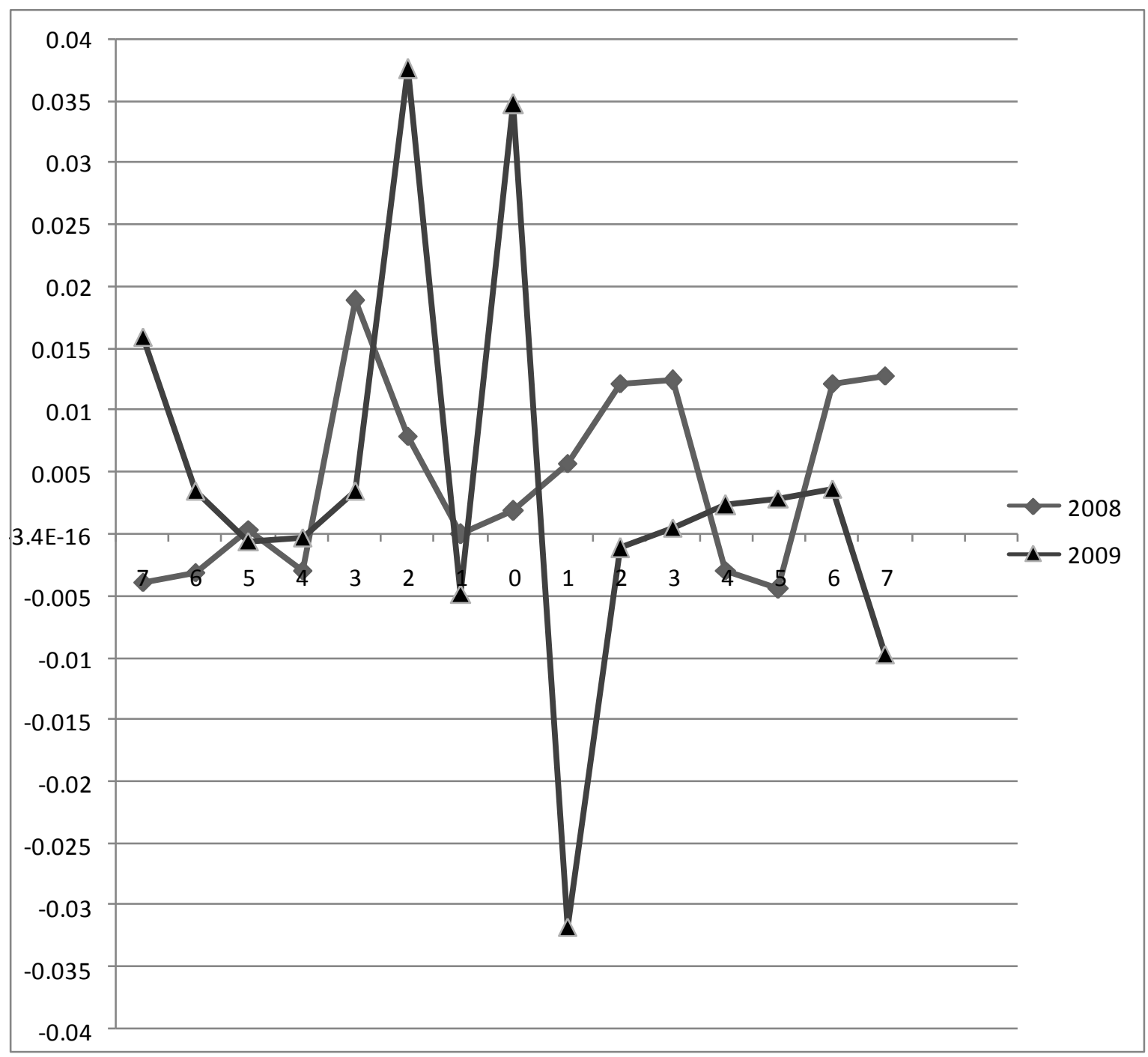

Berdasarkan tabel $\mathrm{X}$ diatas dapat diketahui bahwa sebelum laporan keuangan diumumkan pada tahun 2008 terdapat kecenderungan return saham negatif. Sedangakan setelah laporan keuangan diumumkan, return saham cenderung positif hal ini menunjukkan bahwa ada peningkatan penghasilan para investor yang menyatakan bahwa laporan keuangan ini merupakan kabar baik. Sedangakan pada tahun 2009 terlihat kecenderungan return saham positif sebelum laporan keuangan diumumkan begitu juga setelah laporan keuangan diumumkan, akap tetapi terdapat penurunan return saham negatif setelah laporan keuangan diumumkan hal ini menunjukan perubahan pasar yang berpengaruh pada minat masyarakat untuk berinvestor. 


\section{CREATIVE RESEARCH MANAGEMENT JOURNAL-CRMJ Juni}

Selanjutnya terlihat pada gambar grafik II dimana sebelum laporan keuangan diumumkan kekayaan investor cenderung menurun. Namun semakin mendekati pengumuman laporan keuangan kenaikan kekayaan investor pun makin terlihat kearah yang lebih baik

\section{Pembahasan}

1. Tahun 2008

Dari tabel IX dapat diketahui bahwa return saham sebelum laporan keuangan diumumkan pada awal pengamatan cenderung negatif semakin pendekati tanggal pengumuman laporan keuangan terjadi perubahan kecenderungan kearah positif hal ini menujukkan bahwa investor merespon informasi yang diterima merupakan kabar baik. informasi yang menjadi pedoman investor dalam melihat perkembangan saham dapat berupa perubahan nilai tukar rupiah terhadap dolar, investor terlalu mengharapkan harga yang tinggi, kabar yang beredar luas di masyarakat saat itu dan tingkat suku bunga yang selalu berubah-ubah.

Berdasarkan tabel IX tersebut dapat disimpulkan bahwa ada perbedaan return saham sebelum dam sesudah pengumuman laporan keuangan kearah kenaikan return saham hal ini akan berdampak baik bagi harga saham perusahaaan sehingga menambah return saham positif para investor.

Dari gambar grafik II terlihat penambahan kekayaan investor yang terjadi sebelum pengumuman laporan keuangan, pada saat pengumuman laporan keuangan dan dianggap kabar baik oleh investor terlihat semakin meningkatnya kekayaan investor dari sebelum pengumuman laporan keuangan.

Dari tabel IX dan gambar grafik II tersebut, dapat disimpulkan bahwa ada perbedaan return saham sebelum dan sesudah laporan keuangan di umumkan. Ini terlihat dimana setelah laporan keuangan diumukan terdapat kecenderungan lebih meningkat kearah positif dibanding sebelum laporan keuangan diumumkan.

\section{Tahun 2009}

Dari tabel IX terlihat bahwa sebelum laporan keuangan diumumkan return saham cenderung positif semakin naik mendekati tanggal pengumuman laporan keuangan, sedangakan setelah laporan keuangan diumumkan ada kecenderungan menurun pada $\mathrm{t}_{1}$ dan makin membaik untuk hari selanjutnya

Berdasarkan tabel IX tersebut, dapat disimpulkan bahwa ada perubahan return sahan sebelum dan sesuda laporan keuangan di umumkan, ini dianggap bahwa informasi laporan keuangan yang di dapat oleh para investor tersebut dianggap sebagai berita baik oleh para investor, sehingga setelah mendapatkan informasi mengenai laporan keuangan, pihak investor mulai merespon berita baik tersebut, yang tercermin pada naiknya harga saham perusahaan, sehingga dari kenaikan harga saham inilah investor memeperoleh return saham positif.

Dari gambar grafik II dimana kecenderungan kenaikan return saham positif sebelum laporan keuangan diumumkan namun setelah laporan keuangan diumumkan terdapat kecenderungan negative yang dianggap berita buruk akan 


\section{CREATIVE RESEARCH MANAGEMENT JOURNAL-CRMJ Juni}

tetapi makin membaik kedepanyan, terlihat penambahan kekayaan investor makin naik sesudah turun dari pengumuman laporan keuangan.

Berdasarkan tabel IX dan grafik II tersebut, dapat disimpulkan bahı perubahan return saham sebelum dan sesudah laporan keuangan diumumk ......... terlihat dimana sebelum laporan keuangan diumumkan return sahan cenderung positif dan terjadi penurunan sesudah laporan keuangan diumumkan akat tetapi terjadi peningkatan setelahnya.

\section{KESIMPULAN DAN SARAN \\ Kesimpulan}

Berdasarkan penelitan dan analisa pada pengaruh pengumuman laporan keuangan terhadap return saham pada perusahaan go public di Bursa Efek Indonesia maka dapat disimpulkan bahwa pada tahun 2008 diawal pengamatan return saham cenderung ke arah negatif semakin mendekati tanggal pengumuman laporan keuangan terjadi perubahan kearah positif hal ini dikarenakan informasi yang diterimah investor merupakan berita baik seperti yang mereka harapkan. Sedangkan pada tahun 2009 diawal pengamatan return saham cenderung positif terjadi perubahan kearah negatif semakin mendekati pengumuman laporan keuangan dan kembali membaik ke positif lagi setelah pengumuman laporan keuangan hal ini disebabkan karena informasi yang didapat investor tidak begitu baik seperti yang diharapkannya, karena para investor melihat perubahan return saham dari sudut pandang yang berbeda dan akan melakukan hal yang terbaik yang untuk mendapatkan keuntungan.

Dengan melihat return saham sebelum dan sesudah pengumuman laporan keuangan, baik pengumuman laporan keuangan tahun 2008 dan 2009 terdapat perubahan return, yaitu return yang diperoleh setelah laporan keuangan diumumkan cenderung lebih besar dibandingkan return yang diperoleh sebelum laporan keuangan diumumkan. Hal ini dapat disimpulkan bahwa ada perubahan return saham sebelum dan setelah pengumuman laporan keuangan diumumkan.

Laporan keuangan merupakan sumber informasi yang penting bagi investor karena dengan laporan keuangan inilah investor dapat mengetahui keadaan perusahaan, sehingga ketika laporan keuangan diumumkan, maka akan mempengaruhi return saham. Apabila informasi laporan keuangan tersebut dianggap sebgai berita baik, maka mereka akan memperoleh return positif, sedangkan apabila dianggap sebagai berita buruk, maka akan mengalami return negatif.

\section{Saran}

Perusahaan yang go public perlu lebih terbuka dalam mengumumkan laporan keuangannya. Hal ini dikarenakan laporan keuangan merupakan sumber informasi yang sangat diperlukan bagi investor dalam penentuan pengambilan keputusannya.

Perusahaan yang go public sebaliknya lebih meningkatkan laba dari tahun ke tahun. Sehingga ketika laporan keuangan perusahaan tersebut diumumkan pihak investor dapat menganggap informasi tersebut sebagai berita baik sehingga berpengaruh positif terhadap return saham yang akan diperolah. 


\section{DAFTAR PUSTAKA}

Fahmi, 2011. Analisis Laporan Keuangan, Bandung: Alfabeta, cv.

Halim dan Hanafi, 2003. Analisis Laporan Keuangan, Yogyakarta: UPP AMP YKPN.

Iskandar, 2008. Metodologi Penelitian Pendidikan dan Sosial (kuantitatif dan kualitatif). Jakarta: Gaung Persada Press .

Jogiyanto, 2010. Teori Portofolio dan Analisis Investasi. Yogyakarta. BPFEYogyakarta.

Kasmir, 2006. Manajemen Perbankan, Edisi Revisi, Jakarta: PT RajaGrafindo Persada.

Kasmir, 2008. Bank Dan Lembaga Keuangan Lainya, Edisi Revisi, Jakarta: PT RajaGrafindo Persada.

Munawir, 2004. Analisis Laporan Keuangan Edisi Ke-Empat, Yogyakarta: Liberty Yogyakarta.

Narbuko, Achmadi, 2009. Metodologi Penelitian, Jakarta:Bumi Aksara.

Nitisusantro, Mulyadi, 2010. Kewirausahaan dan Manajemen Usaha kecil. Bandung: Alfabeta.

Putri Dan Hartini, 2012. Analisis Kandungan Informasi Pengumuman Laporan Keuangan Terhadap Return Saham LQ45 Di Bursa Efek Indonesia.

Rusdin, 2008. Pasar Modal. Bandung: Alfabeta.

Riyanto, 2001. Dasar-Dasar Pembelanjaan Perusahaan Edisi Ke-4, Yogyakarta:BPFEYogyakarta.

Triandaru, Santoso, 2006. Bank dan Lembaga Keuangan Lainnya. Jakarta: Selemba Empat.

Sugiyono, 2010. Metode Penelitian Kuantitatif Kualitatif dan R\&D. Bandung:Alfabeta.

Sugiyono, 2003. Statitik untuk penelitian cetakan kelima. Bandung:alfabeta.

Tandelilin, 2010. Portofolio dan Investasi, Teori dan Aplikasi, Edisi Pertama, Yogyakarta:Kanisius.

Undang-Undang no 8 tahun 1995 Tentang Pasar Modal.

www.idx.com. Diakses Juni 2013.

www.yahoofinance.co.id. Diakses Agustus 2013 